\title{
Activity Locus and Geographical Mobility: A Gender Perspective Case of Dar es Salaam, Tanzania
}

\author{
Harriet K Eliufoo ${ }^{1}$, Huba Nguluma ${ }^{2}$ \\ ${ }^{1}$ School of Construction Economics and Management, Ardhi University, P. O. Box 35176, Dar es Salaam, Tanzania \\ ${ }^{2}$ Institute of Human Settlements Studies, Ardhi University, P.O box 33713, Dar es Salaam, Tanzania \\ Correspondence: Harriet K Eliufoo Ardhi University, Dar es Salaam P.O.Box 35176, Dar es Salaam, Tanzania.
}

Received: October 20, 2016

Accepted:November 14, 2016 Available online: November 18, 2016

doi:10.11114/ijsss.v4i12.1995

URL: http://dx.doi.org/10.11114/ijsss.v4i12.1995

\begin{abstract}
The paper has explored the geographical mobility of men and women employed in construction sites. A total of 130 female and male construction workers were interviewed from fifteen construction sites in the City of Dar es Salaam.

The paper has established spatial mobility is gender specific; observing a majo rity of wo men average travel distance to work sites is 3.4 kilometres while that for men site workers is 11.8 kilometres. The study has also established the geographical mobility variation for men and women working in construction sites in Dar es Salaam City are of statistical significant. The empirical research study done conforms to theory that mobility is a resource and access to it is influenced by a society's social construct, cultural values and beliefs, and social economic factors.
\end{abstract}

Keywords: women, geographical mobility, construction industry, Tanzania

\section{Introduction}

Mobility of women in developing countries is guided by a set of complex hierarchies; where factors influencing the gendering of mobility are diverse (Uteng, 2011) and inhibiting (Loukaitou-Siders, 2014). These factors amongst others include: social/cultural norms, transport infrastructure, physical/ area planning and women and men participation in informal sector and micro-cred it schemes. Historically and in most societies, women's mobility in cities has been more hindered than men's (Loukaitou-Siders, 2014).

Increasing women's work outside the home would give women greater control over income within the household though at the expense of even greater pressure on their home (Mbughuni, 1994; Tanzania Gender Networking Programme, 1993). A study of women sand miners in Dar es Salaam established that women prefer to work near their home surroundings to keep pace with domestic responsibilities (Eliufoo and Marobhe, 2001) .The study revealed mobility as a factor why the wo men opted for sand digging activity. The close vicinity to a sand-mining site made it easy for them to undertake the activity. The wo men's predicament was also expressed in a UNDP Poverty Report (1998) that discussed the poverty situation among the poor; stating that poor people face many trade - off between different dimensions of poverty, but women face more than men, and experience poverty differently and often more acu tely

This paper specifically investigates whether gender has influence on mobility for economic earnings. Mobility of men and women employed in construction sites in Dar es Salaam are henceforth being explored. The paper explores whether there is a statistical significance in variation of travel distance to work at construction sites for men and women.

To achieve the said objective the following hypotheses are posited:

"The mean travel distances to work for men and women employed at construction sites are similar"

Null hypothesis Ho: $\mu 1=\mu 2$

$\mathrm{H} 1=$ "The mean travel distances to work for men and women employed at construction sites are not similar"

Alternative hypothesis $\mathrm{Ha}: \mu 1 \neq \mu 2$ 


\section{Method}

The city of Dar es Salaam was considered as it is the largest city in Tanzania and the most active for construction activities. Because of the underly ing socio-economic and historical factors, it attracts a substantial inflow of people and is constantly under pressure for demand of new public and private developments; Dar es Salaam therefore presents an interesting case with challenging exposition of the study phenomena.

Personal interviews were conducted using structured questions for women and men working in Dar es Salaam construction sites. A total of 15 construction sites in Dar es Salaam City were visited and 65 men and 65 women respondents were interviewed. Judgemental sampling was adopted selecting construction sites that were active and had women and men employed as site workers. As typically few women are employed in construction sites, all women found at the sites were interviewed; and this number determined the minimum number of men to be interviewed for each site. Information was collected from respondents to identify their education, age, family sizes, earnings and their geographical mobility. The latter, was collected with respect to employment seeking and is the focus of this paper. Respondents had to give their place of residence and this information was used to establish the distance travelled by male and female site workers from their homes to the work-sites. The data collected is as shown in Table 1 ( See appendix)

Respondents are identified by site number denoted by a chronological numbering from 1-15 reflecting the 15 construction sites used in the sample. The number in brackets denotes the respondents' identification for each site according to gender. Hence for example 8(3) mean site number eight and the third respondent on the site. The travel distance was established based on the route taken by the commercial commuting buses within the city of respondents place of residence and location of construction site where employed.

\section{Results}

It is observed the average distance travelled to work (non- return trip) for women is 3.4 kilometres and 11.9 kilometres. Imply ing women travel only a third of the distance travelled by men in seeking employment at construction sites. One may state women's mobility is limited to a certain geographical region or distance. If this is true, the notion shall be supporting what has been stated that mobility is a "restricted good"; that access to mobility entails processes which are essentially high ly differentiated along the lines of structural differences in society, related to gender, class, race, caste etc. (Uteng, 2011)

However prior to asserting to this notion it is important to rule out whether the result have occurred by chance or are a result of a sampling error. Of more importance is to whether the variation in mobility of men and women employed in construction sites has any statistical significance. An F-test and t-test were done to establish whether the variance in the population means and the sample means are of any significance statistically. The results are as shown in Table 2 and 3 .

For the F-test the following null hypothesis was posited that the population variance of women and men site workers is the same.

$$
\text { Null hypothesis } \mathrm{H} 0: \alpha 1^{2}=\alpha_{2}{ }^{2}
$$

Alternative hypothesis stating the population variance between women and men site workers is not the same.

$$
\text { H1: } \alpha 1^{2} \neq \alpha_{2}{ }^{2}
$$

Table 2. F-Test Two-Sample for Variances

\begin{tabular}{lcc}
\hline & Variable 1(male) & Variable 2 \\
\hline Mean & 11.88615385 & 3.386153846 \\
Variance & 49.26277404 & 7.546836538 \\
Observations & 65 & 65 \\
df & 64 & 64 \\
$\mathrm{~F}$ & 6.52760581 & \\
$\mathrm{P}(\mathrm{F}<=\mathrm{f})$ one-tail & $1.1397 \mathrm{E}-12$ & \\
F Critical one-tail & 1.513287171 & \\
\hline
\end{tabular}

The means of the two populations are far apart; female site workers mean traveldistance is almost a third of the male site workers. A wider variation is observed in the population variance for male site workers where male workers noted travelling long distances from its average majority. A high deviation from the mean distance of travel is noted for female 
site workers though of less magnitude. The results further show that F> F critical hence the null hy pothesis is rejected in favour of the alternative hypothesis; that the variances of the two populations are unequal.

A further analysis made on the sample characteristics establishing the statistical significance of the sample means using the t-test.

The null hypothesis hence stated "The mean travel distance to work sites for men and women employed in construction sites is the same" That is:

$$
\mathrm{H}_{\mathrm{o}:} \mu^{1}=\mu^{2}
$$

And the alternative hypothesis being "The mean travel distance to work sites for men and women employed in construction sites is not the same"

$$
\mathrm{H}_{\mathrm{a}:} \mu^{1} \neq \mu^{2}
$$

The results are shown on Table 3.

Table 3. t-Test: Two-Sample Assuming Unequal Variances

\begin{tabular}{lcc}
\hline & Variable 1 & Variable 2 \\
\hline Mean & 11.88615385 & 3.386153846 \\
Variance & 49.26277404 & 7.546836538 \\
Observations & 65 & 65 \\
Hypothesized Mean Difference & 0 & \\
df & 83 & \\
t Stat & 9.092110347 & \\
P(T<=t) one-tail & $2.13565 \mathrm{E}-14$ & \\
t Critical one-tail & 1.663420175 & \\
P(T<=t) two-tail & $4.27129 \mathrm{E}-14$ & \\
t Critical two-tail & 1.98895978 & \\
\hline
\end{tabular}

It is noted that $\mathrm{t}$ Stat is higher than $\mathrm{t}$ Critical (one- tail) hence the null hypothesis is rejected and adopt that the mean travel distance for men and women to construction work sites is not the same; and this difference is of statistical significance.

\subsection{Respondents'Profile Data (Education, Age, Marital Status and Family Size)}

Data was likewise collected on social economic data of respondents. This included: educational background; marital status; family size work experience and place of residence. Observatory data such as working conditions, specifically health and safety situations at each site, was also collected. From Table 4 it is observed that 52 out of 65 female site workers have primary education, which is a majority. 7 female site workers have secondary education and all of them are machine operators. For male site workers 58 out of the 65 male site workers have vocational training, and 7 have secondary education.

\begin{tabular}{|c|c|c|c|c|c|c|c|}
\hline \multirow{2}{*}{$\mathrm{S} / \mathrm{N}$} & \multirow{2}{*}{ Educational level } & \multicolumn{2}{|c|}{ Female } & \multicolumn{2}{|c|}{ Male } & \multirow[b]{2}{*}{ Total } & \multirow[b]{2}{*}{$\%$} \\
\hline & & $\mathrm{Nr}$. & $\%$ & $\mathrm{Nr}$. & $\%$ & & \\
\hline 1 & Primary School & 52 & 80 & 20 & 31 & 72 & 55 \\
\hline 2 & Secondary School & 7 & 11 & 7 & 11 & 14 & 11 \\
\hline 3 & No Formal education & 4 & 6 & 0 & 0 & 4 & 3 \\
\hline 4 & Vocational & 2 & 3 & 38 & 58 & 40 & 31 \\
\hline Total & & 65 & 100 & 65 & 100 & 130 & 100 \\
\hline
\end{tabular}

Table 4. Male and Female Educational Data 


\subsection{Marital Status and Family Size}

30 out of the 65 female site workers employed in the construction site are single, while $80 \%$ that is 52 out of 65 have children. This indicates a majority of female workers are single parents, with the number of children ranging from one to six. For male site workers, likewise $50 \%$ are married and all have children. Unlike for female respondents, there is no single parenting in male respondents.

Prior to conclusion on data collected, the author acknowledges the limitation that may be inherent resulting from the fact that the construction sites were not randomly selected that existence of both male and female construction workers were the guiding factors; and that the established travel distance is based on an assumption that workers are using local commuter buses to travel from home to construction sites hence route length is based on this assumption.

\section{Discussion and Conclusion}

The study has established structural construct in society influences mobility of women and men towards seeking employment in construction sites. The differences in travel distances between men and women are also significant and real.

The results of the study have also conformed to works of others (Hyun-Mi Kim, 2005; Hanson, 2010) that time spent in domestic responsibilities limit women's spatial mobility. The study has observed a significant number of women are single parents with the number of children ranging from one to six. This asserts Chappel's (2001) connotation that low -income women with childcare obligations have a propensity to seek employment closer to home than men; confirming Kwan's (1999) statement that wo men have a restricted space-time accessibility co mpared to men confirming the assertion of an existence of a gender gap in access to urban opportunities ( Hyun-Mi Kim, 2005 and Kwan, 1999).

A different interpretation of the study could be reflecting on Odufuwa's (2008) work that wo men are more vulnerable to mobility stress; hence the established womens' limited mobility illustrates a risk averse behavior. The relatively low education status for women as compared to the male co-workers in the study further emphasizes the notion that education is among the factors influencing gender mobility (Uteng 2011).

\section{Acknowledgements}

The authors acknowledge the cooperation given by the management of the construction sites visited and the respondents who participated in the interview.

\section{References}

Benett, J. F., \& Davidson, M. J., \& Gale, A. W. (1999). Women in construction a comparative investigation into the expectation and experiences of female and male construction undergraduates and employees. Women in Management Review, 14(7), 273-291. http://dx.doi.org/10.1108/09649429910291122

Bienefield, M. A (1976). Labour Problems in Construction Industry in Tanzania. In: Henry Mapolu (Ed.). W orkers and Management-Tanzania Studies No.4. Tanzania Publishing House Dar es Salaam

Chapple, K. (2001) Time to Work: Job Search Strategies and Commute Time for Women on Welfare in San Francisco, Journal of Urban Affairs, 23(2), 155-173. http://dx.doi.org/10.1111/0735-2166.00081

Dainty, A. R. J., Bagilhole, B. M., \& Neale, R. H. (2001) Male and Female Perspectives on Equality Measures for the UK Construction Sector, Women in Management Review, 16(6), 297-304. http://dx.doi.org/10.1108/EUM0000000005820

Dainty, A. R. J., Neale, R. H., \& Bagilhole, B. M. (1999). Women's careers in large construction companies: Expectations unfulfilled? Career Development International, $4(7)$, 353-358. http:dx.doi.org/10.1108/1362043991029570

Eliufoo, H. K., \& Marhobe, N. (2001). Women Sand Miners in Dar Es Salaam River beds - A Case of Artisan Mining, The Journal of Building and Land Development, 5(3), DUP, Dar es Salaam

Fielden, S. L., Davidson, M. J., Gale A. W., \& Davey, L. C. (2000). Women in Construction: The Untapped Resource, Construction Management and Economics Journal, 18(1), 113 -121. http:dx.doi.org/10.1080/014461900371004

Fielden, S. L., Davidson, M. J., Gale, A. W., \& Davey, L. C, (2001). Women equality and construction, Journal of Management Development, 20(4), 293-305. http://dx.doi.org/10.1108/02621710110388956

Gale, A. W. (1994). Women in non-traditional occupation: the construction industry. Women in Management Review, 9(2), 3-14. http://dx.doi.org/10.1108/ EUM0000000003989

Gale, A. W., \& Cartwright, S. (1995). Women in project management: entry into a male domain? Leadership \& Organization Development Journal, 16(2), 3-8. http://dx.doi.org/10.1108/01437739510082262 
Giunchi, M., \& Emanuel, F. (2016). Gender differences, Career Development International, 21(1), 3-18

Graham, M. W. (1986). The production of the Built Environment No. 8, Bartlett School of Architecture-University College of London

Green, C. (1995). New thinking on gender and the environment, IDS Policy Briefing, unpublished report, University of Dar es salaam, Tanzania.

Hanson, S. (2010). Gender and mobility: new approaches for in forming Sustainability, Journal of Transport Geography 12, 185-195. http://dx.doi.org/10.1080/09663690903498225.

Hyun-Mi, K. (2005). Gender and individual space-time accessibility: A GIS-based Geo - computational approach; dissertation presented in partial fulfillment of the requirements for the Degree Doctor of Philosophy, Graduate School, Ohio State University, 2005.

International Labour Office. (2005). The Dynamics of the Labour Market and Employment in Bangladesh: Gender Dimensions, International Labour Office, Geneva.

Kwan, M. (1999). Gender and individual access to urban opportunities; a study using space time measures, Professional Geographer, 51(2), 210- 227. http://dx.doi.org/10.1111/0033-0124.00158.

Law, R. (1999) Beyond 'women and transport': towards new geographies of gender and daily mobility, Progress in Human Geography, 23(4), 567-588. http://dx.doi.org/10.1191/030913299666161864

Loukaitou-Siders, A. (2014). Fear and safety in transit environments from women's perspective, Security Journal, http://dx.doi.org/10.1057/sj.2014.9.5

Mascarenhas, O., \& Marjorie, M. (1983). Women in Tanzania - An Analytical Bibliography, UPPSALA Sweden.

Mbilinyi, F. (1991). An Article in Mbilinyi Compiler, The Nairobi 85 Manifesto on Women and the Crisis in Africa, IFDA Dossier, 50, University of Dar es Salaam.

Mbughuni, P. (1994). Gender and Poverty Alleviation in Tanzania, Issues from and for Research in M.S.D. Bagachwa (Ed.) Poverty Alleviation in Tanzania Recent Research Issues, Dar es Salaam University Press, 207-241.

Ministry of Community Development and Women Affairs and Children and Bureau of Statistics, Women Affairs and children. (1995). Analysis of African Women and Men, Dar es Salaam.

Odufuwa, B. O. (2008) Gender differentials, vulnerability and mobility stress coping strategies in Nigeria, Journal of Geography and Regional Planning, 1(7), 132-137.

Owusuaa, D. (2012). Gender and Informality in the construction industry in Ghana's Oil City Takoradi, Master's thesis, Department of Geography, University of Bergen.

Ozu mba, A., \& Ozumba, C. (2012). Women in construction in South Africa: Investigating the Feminine Footprint of the South African Construction Industry, Journal of the Advancement of Performance Information and Value 4(1), $28-43$.

Saifuddin, S. M., Dyke, L., \& Rasouli, M. (2013). Gender and careers: a study of persistence in engineering education in Bangladesh, Gender in Management: an International Journal, 28(4), 188-209.

Tanzania Gender Networking Program. (1993). Gender Profile of Tan zania. Tanzania Gender Networking Program, Dar es Salaam.

TBS (1991). Report of first International Workshop on Gender statistics (East, Central and Southern Africa), Tan zania Bureau of Statistics, Dar es Salaam.

UNDP. (1998). Poverty Reduction Report, URT, Construction Industry Policy, Government Printers, Dar es Salaam.

United Nations. (2000). The Worlds Women 2000: Trends and Statistics. A United Nations Publication.

URT, National Bureau of Statistics. (2013). Employment and Earnings Survey 2012 Analytical Report

URT, National Bureau of Statistics. (2015). The Tanzania Integrated Labour force survey 2014 Analytical report

Uteng T. P. (2011). Gendered Bargains of Daily Mobility: Citing cases from both Urban and Rural settings, World Development Report, 2012, Gender Equality and Development. 


\section{Appendix I}

Table 1. Geographical travel distance from home to places of employment by male and female site workers in Dar es Salaam

\begin{tabular}{|c|c|c|c|c|c|c|c|c|c|}
\hline \multicolumn{4}{|c|}{ FEMALE SITE WORKERS } & \multicolumn{6}{|c|}{ MALE SITE WORKERS } \\
\hline & ID & Site location & Residence & $\begin{array}{c}\text { Distance } \\
(\mathrm{Km})\end{array}$ & $\mathrm{S} / \mathrm{N}$. & ID & Site location & Residence & $\begin{array}{c}\text { Distance } \\
(\mathrm{Km})\end{array}$ \\
\hline 1 & $1(1)$ & Tabata & Mabibo & 10.1 & 1 & $1(2)$ & Tabata & Mabibo & 10.1 \\
\hline 2 & $2(1)$ & Mwenge & Sinza & 3.1 & 2 & $2(1)$ & Mwenge & Mbezi Luis & 16.5 \\
\hline 3 & $2(2)$ & Mwenge & $\begin{array}{c}\text { Makumbu } \\
\text { sho }\end{array}$ & 3.1 & 3 & $2(2)$ & Mwenge & $\begin{array}{c}\text { Kimara } \\
\text { stopover }\end{array}$ & 10 \\
\hline 4 & $2(3)$ & Mwenge & Ubungo & 4.7 & 4 & $2(3)$ & Mwenge & Mbezi Luis & 16.5 \\
\hline 5 & $2(4)$ & Mwenge & Magomeni & 8.5 & 5 & $2(4)$ & Mwenge & Magomeni & 8.5 \\
\hline 6 & $2(5)$ & Mwenge & Mwenge & 1 & 6 & $3(1)$ & Mabibo & Mabibo & 2.5 \\
\hline 7 & $2(6)$ & Mwenge & Mwenge & 1 & 7 & $3(2)$ & Mabibo & Tabata & 10.1 \\
\hline 8 & $3(1)$ & Mabibo & Mabibo & 1 & 8 & $3(3)$ & Mabibo & Tabata & 10.1 \\
\hline 9 & $3(2)$ & Mabibo & Mburahati & 3.5 & 9 & $3(4)$ & Mabibo & Tabata & 10.1 \\
\hline 10 & $3(3)$ & Mabibo & Mburahati & 3.5 & 10 & $3(5)$ & Mabibo & Mburahati & 3.5 \\
\hline 11 & $3(4)$ & Mabibo & Segerea & 8.8 & 11 & $3(6)$ & Mabibo & Tabata & 10.1 \\
\hline 12 & $4(1)$ & $\begin{array}{c}\text { Changanyike } \\
\text { ni }\end{array}$ & Goba & 0 & 12 & $3(7)$ & Mabibo & Mabibo & 2.5 \\
\hline 13 & $4(2)$ & $\begin{array}{c}\text { Changanyike } \\
\text { ni }\end{array}$ & Goba & 0 & 13 & $3(8)$ & Mabibo & Tabata & 10.1 \\
\hline 14 & $4(3)$ & $\begin{array}{c}\text { Changanyike } \\
\text { ni }\end{array}$ & Goba & 0 & 14 & $3(9)$ & Mabibo & Ubungo & 7.8 \\
\hline 15 & $4(4)$ & $\begin{array}{c}\text { Changanyike } \\
\text { ni }\end{array}$ & Manzese & 0 & 15 & $3(10)$ & Mabibo & Segerea & 8.8 \\
\hline 16 & $4(5)$ & $\begin{array}{c}\text { Changanyike } \\
\text { ni }\end{array}$ & Manzese & 9.2 & 16 & $4(1)$ & $\begin{array}{c}\text { Changanyike } \\
\text { ni }\end{array}$ & Tabata & 15.4 \\
\hline 17 & $4(6)$ & $\begin{array}{c}\text { Changanyike } \\
\text { ni }\end{array}$ & Manzese & 9.2 & 17 & $4(2)$ & $\begin{array}{c}\text { Changanyike } \\
\text { ni }\end{array}$ & Manzese & 9.2 \\
\hline 18 & $5(1)$ & Mabibo & Mburahati & 3.5 & 18 & $4(3)$ & $\begin{array}{c}\text { Changanyike } \\
\text { ni }\end{array}$ & Manzese & 9.2 \\
\hline 19 & $5(2)$ & Mabibo & Kigogo & 2.9 & 19 & $5(5)$ & Mabibo & Tabata & 10.1 \\
\hline 20 & $5(3)$ & Mabibo & Mburahati & 3.5 & 20 & $5(6)$ & Mabibo & Tabata & 10.1 \\
\hline 21 & $5(4)$ & Mabibo & Mburahati & 3.5 & 21 & $5(7)$ & Mabibo & Segerea & 8.8 \\
\hline 23 & $5(6)$ & Mabibo & Mburahati & 3.5 & 23 & $6(1)$ & Mabibo & $\begin{array}{l}\text { Kibangu- } \\
\text { Ubungo }\end{array}$ & 8.7 \\
\hline 24 & $6(1)$ & Mabibo & Keko & 3.1 & 24 & $6(2)$ & Mabibo & Manzese & 4.2 \\
\hline 25 & $6(2)$ & Mabibo & Manzese & 6.1 & 25 & $6(3)$ & Mabibo & $\begin{array}{c}\text { Gongo/mb } \\
\text { oto }\end{array}$ & 17.3 \\
\hline 26 & $6(3)$ & Mabibo & $\begin{array}{l}\text { Kibangu- } \\
\text { Ubungo }\end{array}$ & 7.8 & 26 & $6(4)$ & Mabibo & Pugu & 19.4 \\
\hline 27 & $6(5)$ & Mabibo & Manzese & 3.3 & 27 & $7(1)$ & Mbagala & Keko & 9.6 \\
\hline 28 & $6(6)$ & Mabibo & Manzese & 3.3 & 28 & $7(2)$ & Mbagala & Tabata & 11.9 \\
\hline 29 & $7(1)$ & Mbagala & Keko & 9.6 & 29 & $7(3)$ & Mbagala & Keko & 9.6 \\
\hline 30 & $7(2)$ & Mbagala & Keko & 9.6 & 30 & $7(4)$ & Mbagala & Keko & 9.6 \\
\hline 31 & $7(3)$ & Mbagala & Keko & 9.6 & 31 & $8(5)$ & Kariakoo & $\begin{array}{c}\text { Gongo/mb } \\
\text { ot }\end{array}$ & 19 \\
\hline 32 & $7(4)$ & Mbagala & Mbagala & 1 & 32 & $8(6)$ & Kariakoo & $\begin{array}{c}\text { Gongo/mb } \\
\text { oto }\end{array}$ & 19 \\
\hline 33 & $7(5)$ & $\begin{array}{l}\text { Mbagala - } \\
\text { Kilwa Rd }\end{array}$ & Mbagala & 1 & 33 & $8(7)$ & Kariakoo & Keko & 3.1 \\
\hline 34 & $8(1)$ & Kariakoo & $\begin{array}{c}\text { Changom } \\
\text { be }\end{array}$ & 3.9 & 34 & $8(8)$ & Kariakoo & Manzese & 6.1 \\
\hline 35 & $8(2)$ & Kariakoo & $\begin{array}{c}\text { Changom } \\
\text { be }\end{array}$ & 3.9 & 35 & $9(4)$ & Magomeni & Mbagala & 11.4 \\
\hline 36 & $8(3)$ & Kariakoo & $\begin{array}{c}\text { Changom } \\
\text { be }\end{array}$ & 3.9 & 36 & $9(5)$ & Magomeni & Mbagala & 11.4 \\
\hline 37 & $8(4)$ & Kariakoo & Manzese & 6.5 & 37 & $9(6)$ & Magomeni & $\begin{array}{c}\text { Gongo/mb } \\
\text { oto }\end{array}$ & 21 \\
\hline 38 & $9(1)$ & Magomeni & Manzese & 4.4 & 38 & $10(1)$ & Upanga East & Mbagala & 12.1 \\
\hline 39 & $9(2)$ & Magomeni & Manzese & 4.4 & 39 & $10(2)$ & Upanga East & Bunju & 43.2 \\
\hline 40 & $9(3)$ & Magomeni & Manzese & 4.4 & 40 & $10(3)$ & Upanga East & Goba & 28,5 \\
\hline 41 & 10 & Upanga East & 0 & 0 & 41 & $10(4)$ & Upanga East & Goba & 27 \\
\hline
\end{tabular}




\begin{tabular}{|c|c|c|c|c|c|c|c|c|c|}
\hline 42 & $11(1)$ & Kawe & Kawe & 1 & 42 & $10(5)$ & Upanga East & Keko & 6 \\
\hline 43 & $11(2)$ & Kawe & Kawe & 1 & 43 & $11(1)$ & Kawe & Goba & 13.3 \\
\hline 44 & $11(3)$ & Kawe & Kawe & 1 & 44 & $11(2)$ & Kawe & Tegeta & 11.2 \\
\hline 45 & $11(4)$ & Kawe & Kawe & 1 & 45 & $11(3)$ & Kawe & Tegeta & 11.2 \\
\hline 46 & $11(5)$ & Kawe & Kawe & 1 & 46 & $11(4)$ & Kawe & Goba & 13.3 \\
\hline 47 & $11(6)$ & Kawe & Kawe & 1 & 47 & $11(5)$ & Kawe & Mbweni & 14.6 \\
\hline 48 & $12(1)$ & Mbezi & Mbezi & 1 & 48 & $11(6)$ & Kawe & Mbweni & 14.6 \\
\hline 49 & $12(2)$ & Mbezi & Mbezi & 2 & 49 & $12(6)$ & Mbezi & Tabata & 11.6 \\
\hline 50 & $12(3)$ & Mbezi & Mbezi & 1 & 50 & $12(7)$ & Mbezi & Tabata & 11.6 \\
\hline 51 & $12(4)$ & Mbezi & Mbezi & 1 & 51 & $12(8)$ & Mbezi & Segerea & 11.9 \\
\hline 52 & $12(5)$ & Mbezi & Mbezi & 2.5 & 52 & $12(9)$ & Mbezi & Segerea & 11.9 \\
\hline 53 & $13(1)$ & Mtongani & Mtongani & 2.5 & 53 & $12(10)$ & Mbezi & Makongo & 10.5 \\
\hline 54 & $13(2)$ & Mtongani & Kunduchi & 4 & 54 & $12(11)$ & Mbezi & Makongo & 10.5 \\
\hline 55 & $14(1)$ & $\begin{array}{l}\text { Temeke } \\
\text { Municipal }\end{array}$ & $\begin{array}{l}\text { Changom } \\
\text { be }\end{array}$ & 2.2 & 55 & $12(12)$ & Mbezi & Mtongani & 27.5 \\
\hline 56 & $14(2)$ & Temeke & Kurasini & 3.5 & 56 & $13(1)$ & Mtongani & Kawe & 8.7 \\
\hline 57 & $14(3)$ & $\begin{array}{l}\text { Municipal } \\
\text { Temeke } \\
\text { Municipal }\end{array}$ & $\begin{array}{l}\text { Changom } \\
\text { be }\end{array}$ & 2.2 & 57 & $13(2)$ & Mtongani & Tabata & 23.5 \\
\hline 58 & $15(1)$ & Kurasini & Kurasini & 1.8 & 58 & $13(3)$ & Mtongani & Goba & 12 \\
\hline 59 & $15(2)$ & Kurasini & Kurasini & 2.5 & 59 & $13(4)$ & Mtongani & Msasani & 21 \\
\hline \multirow[t]{7}{*}{60} & $15(3)$ & Kurasini & Kurasini & 2.5 & 60 & $14(1)$ & Temeke & Mbagala & 3.7 \\
\hline & & & & & 61 & $14(2)$ & Temeke & $\begin{array}{c}\text { Changomb } \\
\text { e }\end{array}$ & 2.2 \\
\hline & & & & & 62 & $14(3)$ & Temeke & Kurasini & 3.7 \\
\hline & & & & & 63 & $14(4)$ & Temeke & $\begin{array}{c}\text { Changomb } \\
\mathrm{e}\end{array}$ & 2.2 \\
\hline & & & & & 64 & $15(1)$ & Kurasini & $\begin{array}{c}\text { Gongo/mb } \\
\text { oto }\end{array}$ & 17.5 \\
\hline & & & & & 65 & $15(2)$ & Kurasini & $\begin{array}{c}\text { Gongo/mb } \\
\text { oto }\end{array}$ & 17.5 \\
\hline & $\begin{array}{c}\text { Average } \\
\text { distance } \\
(\mathrm{km})\end{array}$ & & 3.4 & & $\begin{array}{c}\text { Average } \\
\text { distance } \\
(\mathrm{km})\end{array}$ & & 11.9 & & \\
\hline
\end{tabular}

\section{(c) $)_{E Y}$}

This work is licensed under a Creative Commons Attribution 3.0 License. 